Available Online at www.aextj.com

Agricultural Extension Journal 2021; 5(1):19-41

RESEARCH ARTICLE

\title{
Sustainable Development of Bioenergy from Agriculture Residues and Environment
}

\author{
Abdeen Mustafa Omer \\ Energy Research Institute, Nottingham, United Kingdom
}

Received: 15-01-2021; Revised: 01-02-20201; Accepted: 28-02-2021

\begin{abstract}
This communication discusses a comprehensive review of biomass energy sources, environment, and sustainable development. This includes all the biomass energy technologies, energy efficiency systems, energy conservation scenarios, energy savings, and other mitigation measures necessary to reduce emissions globally. This study highlights the energy problems and their possible saving that can be achieved through the use of biomass energy sources. Furthermore, this piece of work clarifies the background of the study, highlights the potential energy saving that could be achieved. The use of biomass energy source describes the objectives, approach, and scope of the theme. However, to be truly competitive in an open market situation, higher value products are required. Results suggest that biomass technology must be encouraged, promoted, invested, implemented, and demonstrated as a whole while especially in remote rural areas.
\end{abstract}

Key words: Biomass resources, biofuels, energy, environment, wastes, wood fuel

\section{INTRODUCTION}

There is strong scientific evidence that the average temperature of the earth's surface is rising every year. This was a result of the increased concentration of carbon dioxide $\left(\mathrm{CO}_{2}\right)$, and other greenhouse gases (GHGs) in the atmosphere as released by burning fossil fuels..$^{[1,2]}$ This global warming will eventually lead to substantial changes in the world's climate, which will, in turn, have a major impact on human life and the environment. Energy use can be achieved by minimizing the energy demand, by rational energy use, by recovering heat, and the use of more green energies. This will lead to fossil fuels emission reduction. This study was a step toward achieving this goal. The adoption of green or sustainable approaches to the way in which society is run is seen as an important strategy in finding a solution to the energy problem. The key factors of reducing and controlling $\mathrm{CO}_{2}$, which is a major contributor

\section{Address for correspondence:}

Abdeen Mustafa Omer

E-mail: abdeenomer2@yahoo.co.uk to global warming, are the use of alternative approaches to energy generation and the exploration of how these alternatives are used today and may be used in the future as green energy sources. Even with modest assumptions about the availability of land, comprehensive fuel-wood farming programs offer significant energy, economic, and environmental benefits. These benefits would be dispersed in rural areas where they are greatly needed and can serve as linkages for further rural economic development. The nations as a whole would benefit from savings in foreign exchange, improved energy security, and socio-economic improvements. With a ninefold increase in forest plantation cover, the nation's resource base would be greatly improved. The non-technical issues, which have recently gained attention, include:

1) Environmental and ecological factors, for example, carbon sequestration, reforestation, and revegetation.

2) Renewables as a $\mathrm{CO}_{2}$ neutral replacement for fossil fuels.

3) Greater recognition of the importance of renewable energy, particularly modern biomass 
energy carriers, at the policy, and planning levels.

4) Greater recognition of the difficulties of gathering good and reliable biomass energy data, and efforts to improve it.

5) Studies on the detrimental health efforts of biomass energy particularly from traditional energy users.

There is a need for some further development to suit local conditions, to minimize spares holdings, to maximize interchangeability both of engine parts and of the engine application. Emphasis should be placed on full local manufacture. ${ }^{[3]}$ Energy is an essential factor in development since it stimulates, and supports economic growth and development. Fossil fuels, especially oil and natural gas, are finite in extent, and should be regarded as depleting assets, and efforts are oriented to search for new sources of energy. The clamor all over the world for the need to conserve energy and the environment has intensified as traditional energy resources continue to dwindle whilst the environment becomes increasingly degraded. Alternatively energy sources can potentially help fulfill the acute energy demand and sustain economic growth in many regions of the world. Bioenergy is beginning to gain importance in the global fight to prevent climate change. The scope for exploiting organic waste as a source of energy is not limited to direct incineration or burning refuse-derived fuels. Biogas, biofuels, and woody biomass are other forms of energy sources that can be derived from organic waste materials. These biomass energy sources have significant potential in the fight against climate change. ${ }^{[4]}$

Conservation of energy and rationing in some form will however have to be practiced by most countries, to reduce oil imports, and redress balance of payments positions. Meanwhile, development and application of nuclear power and some of the traditional solar, wind, biomass, and water energy alternatives must be set in hand to supplement what remains of the fossil fuels. The encouragement of greater energy use is an essential component of development. In the short-term, it requires mechanisms to enable the rapid increase in energy/capita, and in the longterm we should be working towards a way of life, which makes use of energy efficiency and without the impairment of the environment or of causing safety problems. ${ }^{[5]}$ The objective of this article is to highlight problems related to biomass applications and suggests methods to overcome these problems. This will be achieved through a comprehensive literature review of biomass, their application and the related problems.

The current literature is reviewed regarding the ecological, social, cultural, and economic impacts of biomass technology. This study gives an overview of present and future use of biomass as an industrial feedstock for production of fuels, chemicals, and other materials.

\section{MATERIALS AND METHODS}

The aim of any modern biomass energy systems must be:

- To maximize yields with minimum inputs.

- Utilization and selection of adequate plant materials and processes.

- Optimum use of land, water, and fertilizer.

- Create an adequate infrastructure and strong $\mathrm{R}$ and $\mathrm{D}$ base.

Different techniques and methods employed to maintain and provide specific environments in bioenergy will also be assessed. To evaluate the effectiveness of the suggested methods, a literature review is compiled and presented. Determine the suitability of biomass technology for heating, cooling, and other applications. Verify and document the savings in energy use and demand that biomass may be expected to achieve.

\section{Bioenergy development}

Bioenergy is energy from the sun stored in materials of biological origin. This includes plant matter and animal waste, known as biomass. Plants store solar energy through photosynthesis in cellulose and lignin, whereas animals store energy as fats. When burned, these sugars break down and release energy exothermically, releasing $\mathrm{CO}_{2}$, heat, and steam. The by-products of this reaction can be captured and manipulated to create power, commonly called bioenergy. Biomass is considered renewable because the carbon $(\mathrm{C})$ is taken out of the atmosphere and replenished more quickly than the millions of years required for fossil fuels to form. The use of biofuels to replace fossil fuels contributes to a reduction in 
the overall release of $\mathrm{CO}_{2}$ into the atmosphere and hence helps to tackle global warming. ${ }^{[6]}$

The biomass energy resources are particularly suited for the provision of rural power supplies and a major advantage is that equipment such as flat plate solar driers and wind machines, can be constructed using local resources and without the high capital cost of more conventional equipment. Further advantage results from the feasibility of local maintenance and the general encouragement such local manufacture gives to the buildup of small-scale rural based industry. Table 1 lists the energy sources available. At present, the "non-commercial" fuels wood, crop residues, and animal dung are used in large amounts in the rural areas of developing countries, principally for heating and cooking; the method of use is highly inefficient. Tables 2-4 presented some renewable applications, the most important of energy needs and methods of energy conversion, respectively.

Considerations when selecting power plant include the following:

- Power level - Whether continuous or discontinuous.

- Cost - Initial cost, total running cost including

Table 1: Sources of energy ${ }^{[7]}$

\begin{tabular}{lll}
\hline Energy source & Energy carrier & Energy end-use \\
\hline Vegetation & Fuel-wood & $\begin{array}{l}\text { Cooking } \\
\text { Water heating } \\
\text { Building materials } \\
\text { Animal fodder preparation }\end{array}$ \\
& & $\begin{array}{l}\text { Lighting } \\
\text { Ignition fires }\end{array}$ \\
Oil & Kerosene & Lighting \\
Dry cells & Dry cell batteries & Small appliances \\
& & Transport \\
Muscle power & Animal power & Food preparation for farming \\
& & Transport \\
& & Land preparation for farming \\
Muscle power & Human power & Food preparation (threshing) \\
\hline
\end{tabular}

Table 2: Renewable applications ${ }^{[8]}$

\begin{tabular}{ll}
\hline Systems & Applications \\
\hline Water supply & Rain collection, purification, storage and recycling \\
Wastes disposal & Anaerobic digestion (CH4) \\
Cooking & Methane \\
Food & Cultivate the 1 hectare plot and greenhouse for \\
& four people \\
Electrical demands & Wind generator \\
Space heating & Solar collectors \\
Water heating & Solar collectors and excess wind energy \\
Control system & Ultimately hardware \\
Building fabric & Integration of subsystems to cut costs \\
\hline
\end{tabular}

fuel, maintenance, and capital amortized over life.

- Complexity of operation.

- Maintenance and availability of spares.

- Life and suitability for local manufacture.

The internal combustion engine is a major contributor to rising $\mathrm{CO}_{2}$ emissions worldwide and some pretty dramatic new thinking is needed if our planet is to counter the effects. With its use increasing in developing world economies, there is something to be said for the argument that the vehicles we use to help keep our inner-city environments free from waste, litter, and grime should be at the forefront of developments in lowemissions technology. Materials handled by waste management companies are becoming increasingly valuable. Those responsible for the security of facilities that treat waste or manage scrap will testify to the precautions needed to fight an ongoing battle against unauthorized access by criminals and crucially, to prevent the damage they can cause through theft, vandalism, or even arson. Of particular concern is the escalating level of metal theft, driven by various factors including the demand for metal in rapidly developing economies such as India and China. ${ }^{[9]}$

Table 3: Energy needs in rural areas ${ }^{[8]}$

Transport, for example, small vehicles and boats
Agricultural machinery, for example, two-wheeled tractors
Crop processing, for example, milling
Water pumping
Small industries, for example, workshop equipment
Electricity generation, for example, hospitals and schools
Domestic, for example, cooking, heating, and lighting

Table 4: Methods of energy conversion ${ }^{[10]}$

Muscle power
Internal combustion engines
ciprocating

Rotating

Heat engines

Vapor (Rankine)

Reciprocating

Rotating

Gas Stirling (Reciprocating)

Gas Brayton (Rotating)

Electron gas

Electromagnetic radiation

Hydraulic engines

Wind engines (wind machines)

Electrical/mechanical 
There is a need for greater attention to be devoted to this field in the development of new designs, the dissemination of information and the encouragement of its use. International and government bodies and independent organizations all have a role to play in biomass energy technologies. Environment has no precise limits because it is in fact a part of everything. Indeed, environment is, as anyone probably already knows, not only flowers blossoming or birds singing in the spring, or a lake surrounded by beautiful mountains. It is also human settlements, the places where people live, work, rest, the quality of the food we eat, the noise or silence of the street they live in. Environment is not only the fact that our cars consume a good deal of energy and pollutes the air but also, that we often need them to go to work and for holidays. Obviously man uses energy just as plants, bacteria, mushrooms, bees, fish, and rats do [Figure 1]. Man largely uses solar energyfood, hydropower, wood and thus participates harmoniously in the natural flow of energy through the environment. However, man also uses oil, gas, coal, and nuclear power. We always modify our environment with or without this source of energy. ${ }^{[11]}$ Economic importance of environmental issue is increasing, and new technologies are expected to reduce pollution derived both from productive processes and products, with costs that are still unknown. This is due to market uncertainty, weak appropriability regime, lack of a dominant design, and difficulties in reconfiguring organizational routines. The degradation of the global environment is one of the most serious energy issues. ${ }^{[12]}$

\section{ENERGY USE AND THE ENVIRONMENT}

The range of waste treatment technologies that are tailored to produce bioenergy is growing. There are a number of key areas of bioenergy from wastes

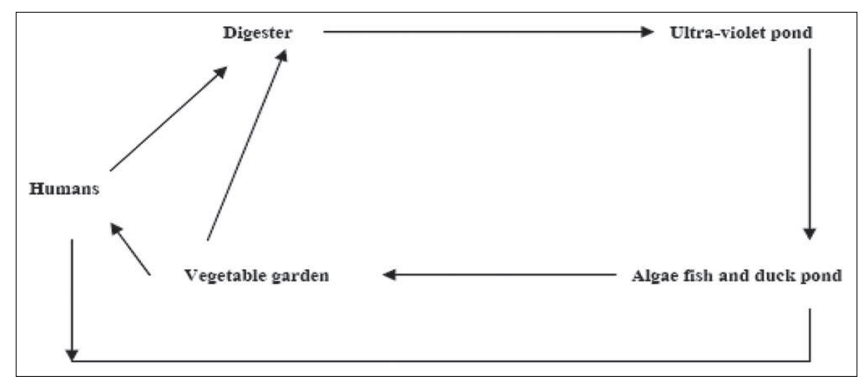

Figure 1: Biomass utilization cycle concepts ${ }^{[14]}$ including (but not limited to) biogas, biofuels, and Bioheat [Tables 5 and 6].

When considering using bioenergy, it is important to take into account the overall emission of carbon in the process of electricity production. Energy use is one of several essential components for every country:

- The overall situation and the implications of increased energy use in the future.

The problem of the provision of power in rural areas, includes the consideration of energy resources and energy conversion. In addition to the drain on resources, such an increase in consumption consequences, together with the increased hazards of pollution and the safety problems associated with a large nuclear fission programs. It would be equally unacceptable to suggest that the difference in energy between the developed and developing countries and prudent for the developed countries to move toward a way of life which, whilst maintaining or even increasing quality of life, reduce significantly the energy consumption per capita. Such savings can be achieved in a number of ways:

- Improved efficiency of energy use, for example, environmental cost of thermal insulation must be taken into account, energy recovery, and total energy.

Table 5: Annual GHG emissions from different types of power plants ${ }^{[13]}$

\begin{tabular}{|c|c|c|c|c|}
\hline \multirow{2}{*}{$\begin{array}{l}\text { Primary } \\
\text { source of } \\
\text { energy }\end{array}$} & \multicolumn{2}{|c|}{$\begin{array}{l}\text { Emissions }\left(\times 10^{3}\right. \\
\left.\text { metric tons } \mathrm{CO}_{2}\right)\end{array}$} & \multirow{2}{*}{$\begin{array}{c}\text { Waste } \\
\left(\times 10^{3} \text { metric }\right. \\
\left.\text { tons } \mathrm{CO}_{2}\right)\end{array}$} & \multirow[t]{2}{*}{$\begin{array}{l}\text { Area } \\
\left(\mathbf{k m}^{2}\right)\end{array}$} \\
\hline & Atmosphere & Water & & \\
\hline Coal & 380 & $7-41$ & $60-3000$ & 120 \\
\hline Oil & $70-160$ & $3-6$ & Negligible & $70-84$ \\
\hline Gas & 24 & 1 & - & 84 \\
\hline Nuclear & 6 & 21 & 2600 & 77 \\
\hline
\end{tabular}

Table 6: Energy consumption per person ${ }^{[13]}$

\begin{tabular}{lcc}
\hline Region & $\begin{array}{c}\text { Population } \\
\text { (millions) }\end{array}$ & $\begin{array}{c}\text { Energy per } \\
\text { person }\left(\text { Watt } \mathbf{m}^{\mathbf{2}} \text { ) }\right.\end{array}$ \\
\hline Africa & 820 & 0.54 \\
Asia & 3780 & 2.74 \\
Central America & 180 & 1.44 \\
North America & 335 & 0.34 \\
South America & 475 & 0.52 \\
Western Europe & 445 & 2.24 \\
Eastern Europe & 130 & 2.57 \\
Oceania & 35 & 0.08 \\
Russia & 330 & 0.29 \\
\hline
\end{tabular}


- Conservation of energy resources by design for long life and recycling rather than the short life throwaway product and systematic replanning of our way of life, for example, in the field of transport. Energy ratio (Er) is defined as the ratio of energy content $(\mathrm{Ec})$ of the food product/Energy input (Ei) to produce the food.

$\mathrm{Er}=\mathrm{Ec} / \mathrm{Ei}$

Combined heat and power (CHP) installations are quite common in greenhouses, which grow highenergy, input crops (e.g., salad vegetables, and pot plants). Scientific assumptions for a short-term energy strategy suggest that the most economically efficient way to replace the thermal plants is to modernize existing power plants to increase their energy efficiency and to improve their environment performance (Pernille, 2004) [Tables 7 and 8].

However, utilization of wind power and the conversion of gas-fired CHP plants to biomass would significantly reduce the dependence on imported fossil fuels. Although a lack of generating capacity is forecasted in the long-term, utilization of the existing renewable energy potential and the huge possibilities for increasing energy efficiency are sufficient to meet future energy demands in the short-term. ${ }^{[15]}$

A total shift toward a sustainable energy system is a complex and long process, but is one that can be achieved within a period of about 20 years.
Implementation will require initial investment, long-term national strategies, and action plans. However, the changes will have a number of benefits including a more stable energy supply than at present and major improvement in the environmental performance of the energy sector, and certain social benefits [Figure 2]. A vision that used methodologies and calculations based on computer modeling can utilized:

- Data from existing governmental programs.

- Potential renewable energy sources and energy efficiency improvements.

- Assumptions for future economy growth.

- Information from studies and surveys on the recent situation in the energy sector.

The main advantages are related to energy, agriculture, and environment problems, are foreseeable both at national and international level can be summarized as follows:

- Reduction of dependence on import of energy and related products.

- Reduction of environmental impact of energy production (greenhouse effect, air pollution, and waste degradation).

- Substitution of food crops and reduction of food surpluses and of related economic burdens, and development of new know-how and production of technological innovation.

- Utilization of marginal lands and of set aside

Table 7: Summary of material recycling practices in the construction sector ${ }^{[15]}$

\begin{tabular}{|c|c|c|}
\hline $\begin{array}{l}\text { Construction and } \\
\text { demolition material }\end{array}$ & Recycling technology options & Recycling product \\
\hline Asphalt & $\begin{array}{l}\text { Cold recycling: heat generation; Minnesota process; parallel } \\
\text { drum process; elongated drum; microwave asphalt recycling } \\
\text { system; Finfalt; surface regeneration }\end{array}$ & Recycling asphalt; asphalt aggregate \\
\hline Brick & Burn to ash, crush into aggregate & Slime burn ash; filling material; hardcore \\
\hline Concrete & Crush into aggregate & $\begin{array}{l}\text { Recycling aggregate; cement replacement; protection of levee; } \\
\text { backfilling; filter }\end{array}$ \\
\hline Ferrous metal & Melt; reuse directly & Recycled steel scrap \\
\hline Glass & $\begin{array}{l}\text { Reuse directly; grind to powder; polishing; crush into } \\
\text { aggregate; burn to ash }\end{array}$ & $\begin{array}{l}\text { Recycled window unit; glass fiber; filling material; } \\
\text { tile; paving block; asphalt; recycled aggregate; cement } \\
\text { replacement; manmade soil }\end{array}$ \\
\hline Masonry & Crush into aggregate; heat to $900^{\circ} \mathrm{C}$ to ash & Thermal insulating concrete; traditional clay \\
\hline Non-ferrous metal & Melt & Recycled metal \\
\hline Paper and cardboard & Purification & Recycled paper \\
\hline Plastic & $\begin{array}{l}\text { Convert to powder by cryogenic milling; clopping; crush into } \\
\text { aggregate; burn to ash }\end{array}$ & $\begin{array}{l}\text { Panel; recycled plastic; plastic lumber; recycled aggregate; } \\
\text { landfill drainage; asphalt; manmade soil }\end{array}$ \\
\hline Timber & $\begin{array}{l}\text { Reuse directly; cut into aggregate; blast furnace deoxidization; } \\
\text { gasification or pyrolysis; chipping; molding by pressurizing } \\
\text { timber chip under steam and water }\end{array}$ & $\begin{array}{l}\text { Whole timber; furniture and kitchen utensils; lightweight } \\
\text { recycled aggregate; source of energy; chemical production; } \\
\text { wood-based panel; plastic lumber; geofibre; insulation board }\end{array}$ \\
\hline
\end{tabular}


Table 8: Final energy projections including biomass $(\text { Mtoe })^{[17]}$

\begin{tabular}{|c|c|c|c|c|}
\hline & Biomass & $\begin{array}{c}\text { Conventional } \\
\text { energy }\end{array}$ & Total & $\begin{array}{c}\text { Share of } \\
\text { biomass }(\%)\end{array}$ \\
\hline \multicolumn{5}{|l|}{ Region 2011} \\
\hline Africa & 205 & 136 & 341 & 60 \\
\hline China & 206 & 649 & 855 & 24 \\
\hline East Asia & 106 & 316 & 422 & 25 \\
\hline Latin America & 73 & 342 & 415 & 18 \\
\hline South Asia & 235 & 188 & 423 & 56 \\
\hline $\begin{array}{l}\text { Total } \\
\text { developing } \\
\text { countries }\end{array}$ & 825 & 1632 & 2457 & 34 \\
\hline $\begin{array}{l}\text { Other } \\
\text { non-OECD* } \\
\text { countries }\end{array}$ & 24 & 1037 & 1061 & 2 \\
\hline $\begin{array}{l}\text { Total } \\
\text { non-OECD* } \\
\text { countries }\end{array}$ & 849 & 2669 & 3518 & 24 \\
\hline $\begin{array}{l}\text { OECD } \\
\text { countries }\end{array}$ & 81 & 3044 & 3125 & 3 \\
\hline World & 930 & 5713 & 6643 & 14 \\
\hline \multicolumn{5}{|l|}{ Region 2020} \\
\hline Africa & 371 & 266 & 637 & 59 \\
\hline China & 224 & 1524 & 1748 & 13 \\
\hline East Asia & 118 & 813 & 931 & 13 \\
\hline \multicolumn{5}{|l|}{ Region 2011} \\
\hline Latin America & 81 & 706 & 787 & 10 \\
\hline South Asia & 276 & 523 & 799 & 35 \\
\hline $\begin{array}{l}\text { Total } \\
\text { developing } \\
\text { countries }\end{array}$ & 1071 & 3825 & 4896 & 22 \\
\hline $\begin{array}{l}\text { Other } \\
\text { non-OECD* } \\
\text { countries }\end{array}$ & 26 & 1669 & 1695 & 2 \\
\hline $\begin{array}{l}\text { Total } \\
\text { non-OECD* } \\
\text { countries }\end{array}$ & 1097 & 5494 & 6591 & 17 \\
\hline $\begin{array}{l}\text { OECD } \\
\text { countries }\end{array}$ & 96 & 3872 & 3968 & 2 \\
\hline World & 1193 & 9365 & 10558 & 11 \\
\hline
\end{tabular}

*Organization for Economic Co-operation and Development

lands and reduction of related socio-economic and environmental problems (soil erosion, urbanization, landscape deterioration, etc.).

In some countries, a wide range of economic incentives and other measures are already helping to protect the environment. These include:

- Taxes and user charges that reflect the costs of using the environment, for example, pollution taxes and waste disposal charges.

- Subsidies, credits, and grants that encourage environmental protection.
- Deposit-refund systems that prevent pollution on resource misuse and promote product reuse or recycling.

- Financial enforcement incentives, for example, fines for non-compliance with environmental regulations.

- Tradable permits for activities that harm the environment.

District Heating (DH) also known as community heating can be a key factor to achieve energy savings, reduce $\mathrm{CO}_{2}$ emissions and at the same time provide consumers with a high quality heat supply at a competitive price. The $\mathrm{DH}$ should generally only be considered for areas where the heat density is sufficiently high to make $\mathrm{DH}$ economical. In countries like Denmark $\mathrm{DH}$ may today be economical even to new developments with lower density areas due to the high level of taxation on oil and gas fuels combined with the efficient production of the DH. To improve the opportunity for the $\mathrm{DH}$ local councils can adapt the following plan:

- Analyze the options for heat supply during local planning stage.

- In areas where DH is the least cost solution it should be made part of the infrastructure just like for instance water and sewage connecting all existing and new buildings.

- Where possible all public buildings should be connected to the DH.

- The government provides low interest loans or funding to minimize conversion costs for its citizens.

- Use other powers, for instance national legislation to ensure the most economical development of the heat supply and enable an obligation to connect buildings to a DH scheme. Denmark has broadly seen three scales of the CHP which were largely implemented in the following chronological order: ${ }^{[15]}$

- $\quad$ Large-scale CHP in cities (>50 MWe).

- Small (5 kWe-5 MWe) and medium-scale (5-50 MWe).

- Industrial and small-scale CHP.

CHP installations are quite common in greenhouses, which grow high-energy, input crops (e.g., salad vegetables, and pot plants). Most of the heat is produced by large CHP plants (gas-fired combined cycle plants using natural gas, biomass, waste, or 


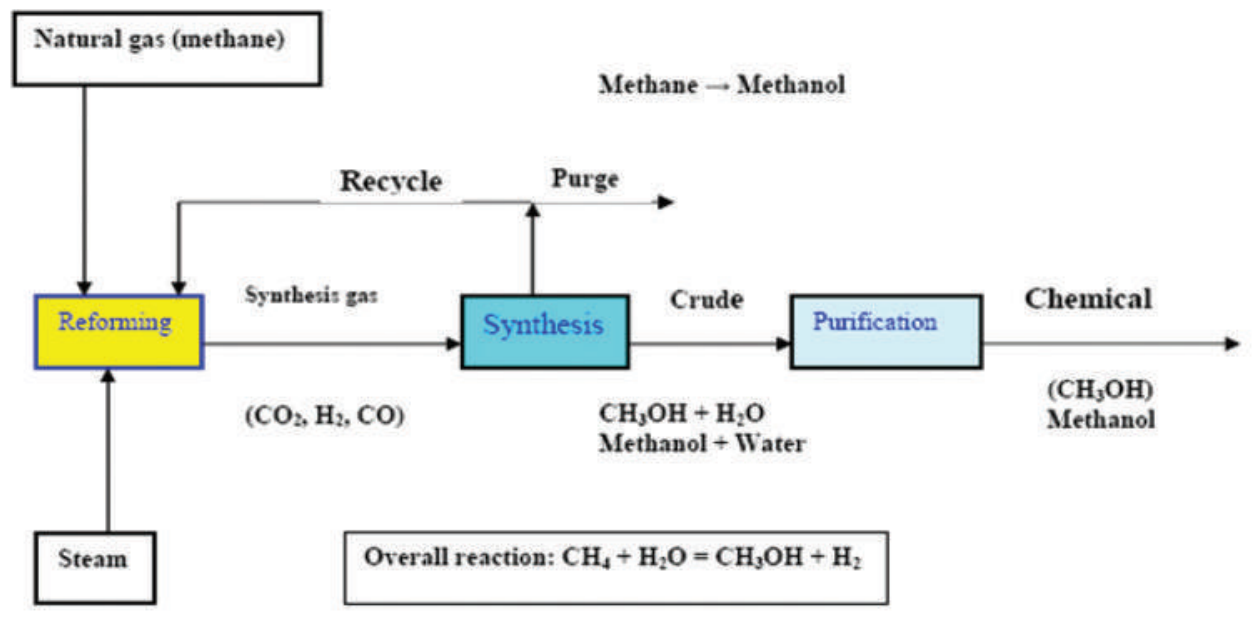

Figure 2: Schematic diagram shows methanol production ${ }^{[16]}$

biogas). $\mathrm{DH}$ is energy efficient because of the way the heat is produced and the required temperature level is an important factor. Buildings can be heated to temperature of $21^{\circ} \mathrm{C}$ and domestic hot water can be supplied with a temperature of $55^{\circ} \mathrm{C}$ using energy sources that are most efficient when producing low temperature levels $\left(<95^{\circ} \mathrm{C}\right)$ for the $\mathrm{DH}$ water. Most of these heat sources are $\mathrm{CO}_{2}$ neutral or emit low levels. Only a few of these sources are available to small individual systems at a reasonably cost, whereas DH schemes because of the plant's size and location can have access to most of the heat sources and at a low cost. Low temperature $\mathrm{DH}$, with return temperatures of around $30-40^{\circ} \mathrm{C}$ can utilize the following heat sources:

- Efficient use of the CHP by extracting heat at low calorific value $(\mathrm{CV})$.

- Efficient use of biomass or gas boilers by condensing heat in economizers [Table 8].

- Efficient utilization of geothermal energy.

- Direct utilization of excess low temperature heat from industrial processes.

- Efficient use of large-scale solar heating plants. Heat tariffs may include a number of components such as a connection charge, a fixed charge and a variable energy charge. Furthermore, consumers may be incentivized to lower the return temperature. Hence, it is difficult to generalize but the heat practice for any DH company no matter what the ownership structure can be highlighted as follows:

- To develop and maintain a development plan for the connection of new consumers and to evaluate the options for least cost production of heat.
- To implement the most competitive solutions by signing agreements with other companies or by implementing own investment projects.

- To monitor all internal costs and with the help of benchmarking, and improve the efficiency of the company.

- To maintain a good relationship with the consumer and deliver heat supply services at a sufficient quality.

Installing $\mathrm{DH}$ should be pursued to meet the objectives for improving the environment through the improvement of energy efficiency in the heating sector. At the same time, DH can serve the consumer with a reasonable quality of heat at the lowest possible cost. The variety of possible solutions combined with the collaboration between individual companies, the $\mathrm{DH}$ association, the suppliers, and consultants can, as it has been in Denmark, be the way forward for developing DH in the United Kingdom. Implementation will require initial investment, long-term national strategies, and action plans. However, the changes will have a number of benefits including a more stable energy supply than at present and major improvement in the environmental performance of the energy sector, and certain social benefits (Pernille, 2004).

\section{BIOMASS UTILIZATION AND DEVELOPMENT OF CONVERSION TECHNOLOGIES}

Sustainable energy is energy that, in its production or consumption, has minimal negative impacts 
on human health and the healthy functioning of vital ecological systems, including the global environment. It is an accepted fact that renewable energy is a sustainable form of energy, which has attracted more attention during recent years. A great amount of renewable energy potential, environmental interest, as well as economic consideration of fossil fuel consumption and high emphasis of sustainable development for the future will be needed. Explanations for the use of inefficient agricultural-environmental polices include: The high cost of information required to measure benefits on a site-specific basis, information asymmetries between government agencies and farm decision makers that result in high implementation costs, distribution effects and political considerations. Achieving the aim of agric-environment schemes through:

- Sustain the beauty and diversity of the landscape.

- Improve and extend wildlife habitats.

- Conserve archaeological sites and historic features.

- Improve opportunities for countryside enjoyment.

- Restore neglected land or features, and

- Create new habitats and landscapes.

The data required to perform the trade-off analysis simulation can be classified according to the divisions given in Table 9: The overall system or individual plants, and the existing situation or future development. The effective economic utilizations of these resources are shown in Table 10, but their use is hindered by many problems such as those related to harvesting, collection, and transportation, besides the sanitary control regulations. Biomass energy is experiencing a surge in an interest stemming from a combination of factors, for example, greater recognition of its current role and future potential contribution as a modern fuel, global environmental benefits, its development and entrepreneurial opportunities. Possible routes of biomass energy development are shown in Table 11.

The key to successful future appears to lie with successful marketing of the treatment by products. There is also potential for using solid residue in the construction industry as a filling agent for concrete. Research suggests that the composition of the residue locks metals within the material, thus preventing their escape and any subsequent negative effect on the environment. ${ }^{[19]}$ The use of biomass through direct combustion has long been, and still is the most common mode of biomass utilization as shown in Tables 9-11. Examples for dry (thermo-chemical) conversion processes are charcoal making from wood (slow pyrolysis), gasification of forest and agricultural residues (fast pyrolysis - this is still in demonstration phase), and of course, direct combustion in stoves, furnaces, etc. Wet processes require substantial amount

Table 9: Classifications of data requirements ${ }^{[20]}$

\begin{tabular}{lll}
\hline Item & Plant data & System data \\
\hline Existing data & Size & Peak load \\
& Life & Load shape \\
& Cost (fixed and var. O and M) & Capital costs \\
& Forced outage & Fuel costs \\
& Maintenance & Depreciation \\
& Efficiency & Rate of return \\
& Fuel & Taxes \\
& Emissions & \\
Future data & All of above, plus & System lead growth \\
& Capital costs & Fuel price growth \\
& Construction trajectory & Fuel import limits \\
& Date in service & Inflation \\
\hline
\end{tabular}

Table 10: Agricultural residues routes for development ${ }^{[20]}$

\begin{tabular}{|c|c|c|c|}
\hline Source & Process & Product & End use \\
\hline $\begin{array}{l}\text { Agricultural } \\
\text { residues }\end{array}$ & $\begin{array}{l}\text { Direct } \\
\text { Processing } \\
\text { Processing } \\
\text { Carbonization } \\
\text { Fermentation }\end{array}$ & $\begin{array}{l}\text { Combustion } \\
\text { Briquettes } \\
\text { Carbonization } \\
\text { (small-scale) } \\
\text { Briquettes } \\
\text { Carbonized } \\
\text { Biogas }\end{array}$ & $\begin{array}{l}\text { Rural poor } \\
\text { Urban household } \\
\text { Industrial use } \\
\text { Industrial use } \\
\text { Limited household use } \\
\text { Rural household } \\
\text { (self-sufficiency) } \\
\text { Urban fuel } \\
\text { Energy services } \\
\text { Household } \\
\text { Industry }\end{array}$ \\
\hline $\begin{array}{l}\text { Agricultural, } \\
\text { and animal } \\
\text { residues }\end{array}$ & $\begin{array}{l}\text { Direct } \\
\text { Briquettes } \\
\text { Carbonization } \\
\text { Carbonization } \\
\text { Fermentation }\end{array}$ & $\begin{array}{l}\text { Combustion } \\
\text { Direct } \\
\text { combustion } \\
\text { Carbonized } \\
\text { Briquettes } \\
\text { Biogas }\end{array}$ & $\begin{array}{l}\text { (Save or less } \\
\text { efficiency as wood) } \\
\text { (Similar end use } \\
\text { devices or improved) } \\
\text { Use } \\
\text { Briquettes use } \\
\text { Use }\end{array}$ \\
\hline
\end{tabular}

Table 11: Effective biomass resource utilization ${ }^{[22]}$

\begin{tabular}{lll}
\hline Subject & Tools & Constraints \\
\hline Utilization and & Stumpage fees & Policy \\
land clearance for & Control & Fuel-wood planning \\
agriculture expansion & Extension & Lack of extension \\
& Conversion & Institutional \\
& Technology & \\
Utilization of & Briquetting & Capital \\
agricultural residues & Carbonization & Pricing \\
& Carbonization & Policy and legislation \\
& and briquetting & Social acceptability \\
& Fermentation & \\
& Gasification & \\
\hline
\end{tabular}


of water to be mixed with the biomass. Biomass technologies include:

- Briquetting.

- Improved stoves.

- Biogas.

- Improved charcoal.

- Carbonization.

- Gasification.

The increased demand for gas and petroleum, food crops, fish, and large sources of vegetative matter mean that the global harvesting of carbon has in turn intensified. It could be said that mankind is mining nearly everything except its waste piles. It is simply a matter of time until the significant carbon stream present in municipal solid waste (MSW) is fully captured. In the meantime, the waste industry needs to continue on the pathway to increased awareness and better-optimized biowaste resources. Optimization of waste carbon may require widespread regulatory drivers (including strict limits on the landfilling of organic materials), public acceptance of the benefits of waste carbon products for soil improvements/crop enhancements, and more investment in capital facilities. ${ }^{[21]}$ In short, a significant effort will be required to capture a greater portion of the carbon stream and put it to beneficial use. From the standpoint of waste practitioners, further research and pilot programs are necessary before the available carbon in the waste stream can be extracted in sufficient quality and quantities to create the desired end products. Other details need to be ironed out too, including measurement methods, diversion calculations, sequestration values, and determination of acceptance contamination thresholds. ${ }^{[22]}$

\section{Briquette production}

Charcoal stoves are very familiar to African society. ${ }^{[18]}$ As for the stove technology, the present charcoal stove can be used and can be improved upon for better efficiency. This energy term will be of particular interest to both urban and rural households and all the income groups due to the simplicity, convenience, and lower air polluting characteristics. However, the market price of the fuel together with that of its end-use technology may not enhance its early high market penetration especially in the urban low income and rural households.
Briquetting is the formation of a charcoal (an energy-dense solid fuel source) from otherwise wasted agricultural and forestry residues. One of the disadvantages of wood fuel is that it is bulky with a low energy density and is therefore enquire to transport. Briquette formation allows for a more energy-dense fuel to be delivered, thus reducing the transportation cost and making the resource more competitive. It also adds some uniformity, which makes the fuel more compatible with systems that are sensitive to the specific fuel input. ${ }^{[23]}$

\section{Improved cook stoves}

Traditional wood stoves can be classified into four types: Three stone, metal cylindrical shaped, metal tripod, and clay type. ${ }^{[24]}$ Another area in which rural energy availability could be secured where woody fuels have become scarce, are the improvements of traditional cookers and ovens to raise the efficiency of fuel saving. Furthermore, to provide a constant fuel supply by planting fast growing trees. The rural development is essential and economically important since it will eventually lead to better standards of living, people's settlement, and selfsufficient in the following:

- Food and water supplies.

- Better services in education and health care.

- Good communication modes.

\section{Biogas technology}

Biogas technology cannot only provide fuel, but is also important for comprehensive utilization of biomass forestry, animal husbandry, fishery, agricultural economy, protecting the environment, realizing agricultural recycling, as well as improving the sanitary conditions, in rural areas. The introduction of biogas technology on wide scale has implications for macro planning such as the allocation of government investment and effects on the balance of payments. Factors that determine the rate of acceptance of biogas plants, such as credit facilities and technical backup services, are likely to have to be planned as part of general macro-policy, as do the allocation of research and development funds. ${ }^{[25]}$

Biogas is a generic term for gases generated from the decomposition of organic material. As the 
material breaks down, methane $\left(\mathrm{CH}_{4}\right)$ is produced as shown in Figure 3. Sources that generate biogas are numerous and varied. These include landfill sites, wastewater treatment plants, and anaerobic digesters. Landfills and wastewater treatment plants emit biogas from decaying waste. To date, the waste industry has focused on controlling these emissions to our environment and in some cases, tapping this potential source of fuel to power gas turbines, thus generating electricity. The primary components of landfill gas are methane $\left(\mathrm{CH}_{4}\right), \mathrm{CO}_{2}$, and nitrogen $\left(\mathrm{N}_{2}\right)$. The average concentration of methane is $\sim 45 \%, \mathrm{CO}_{2}$ is $\sim 36 \%$, and nitrogen is $\sim 18 \%$. Other components in the gas are oxygen $\left(\mathrm{O}_{2}\right)$, water vapor, and trace amounts of a wide range of non-methane organic compounds (NMOCs).

For hot water and heating, renewables contributions come from biomass power and heat, geothermal direct heat, ground source heat pumps, and rooftop solar hot water and space heating systems. Solar assisted cooling makes a very small but growing contribution. When it comes to the installation of large amounts of the PV, the cities have several important factors in common. These factors include: ${ }^{[25]}$
- A strong local political commitment to the environment and sustainability.

- The presence of municipal departments or offices dedicated to the environment, and sustainability or renewable energy.

- Information provision about the possibilities of renewables.

- Obligations that some or all buildings include renewable energy.

\section{Improved forest and tree management}

Dry cell batteries are a practical but expensive form of mobile fuel that is used by rural people when moving around at night and for powering radios and other small appliances. The high cost of dry cell batteries is financially constraining for rural households, but their popularity gives a good indication of how valuable a versatile fuel like electricity is in rural area. Dry cell batteries can constitute an environmental hazard unless they are recycled in a proper fashion. Direct burning of fuelwood and crop residues constitute the main usage

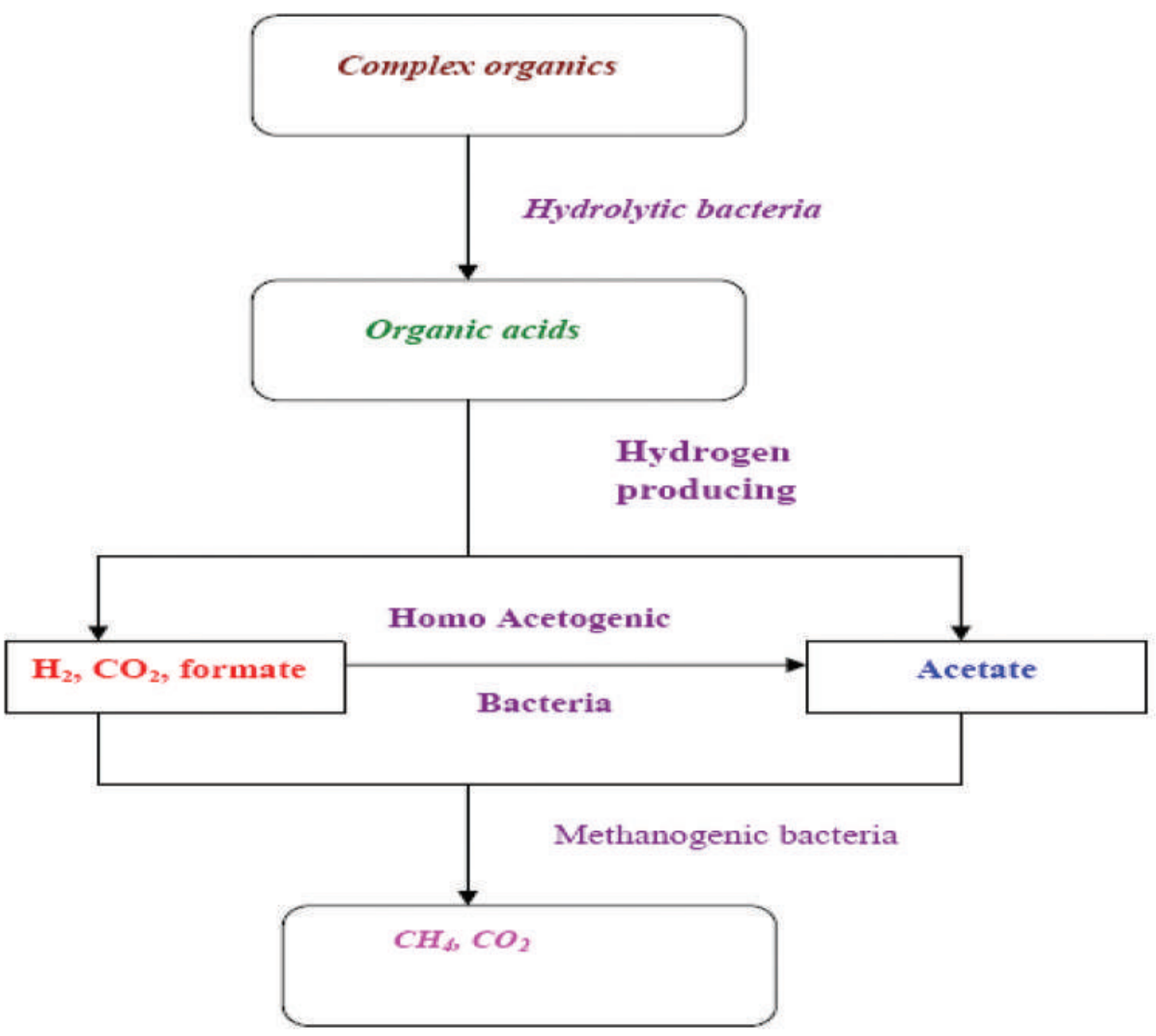

Figure 3: Biogas production process ${ }^{[26]}$ 
of biomass, as is the case with many developing countries. However, the direct burning of biomass in an inefficient manner causes economic loss and adversely affects human health. To address the problem of inefficiency, research centers around the world have investigated the viability of converting the resource to a more useful form, namely, solid briquettes and fuel gas [Figure 4]. Biomass resources play a significant role in energy supply in all developing countries. Biomass resources should be divided into residues or dedicated resources, the latter including firewood and charcoal can also be produced from forest residues [Table 12].

Implementing measures for energy efficiency increase at the demand side and in the energy transformation sector is important. It is common practice to dispose of this waste wood in landfill where it slowly degraded and takes up valuable void space. This wood is a good source of energy and is an alternative to energy crops. Agricultural wastes are abundantly available globally and can be converted to energy and useful chemicals by a number of microorganisms. The success of promoting any technology depends on careful planning, management, implementation, training, and monitoring. Main features of gasification project are:

- Networking and institutional development/ strengthening.
- Promotion and extension.

- Construction of demonstration projects.

- Research and development, and training and monitoring.

\section{Gasification processes}

Gasification is based on the formation of a fuel gas (mostly $\mathrm{CO}$ and $\mathrm{H}_{2}$ ) by partially oxidizing raw solid fuel at high temperatures in the presence of steam or air. The technology can use wood chips, groundnut shells, sugar cane bagasse, and other similar fuels to generate capacities from $3 \mathrm{~kW}$ to $100 \mathrm{~kW}$. Three types of gasifier designs have been developed to make use of the diversity of fuel inputs and to meet the requirements of the product gas output (degree of cleanliness, composition, heating value, etc.). The requirements of gas for various purposes, and a comparison between biogas and various commercial fuels in terms of $\mathrm{CV}$, and thermal efficiency are presented in Table 13. Sewage sludge is rich in nutrients such as nitrogen and phosphorous. It also contains valuable organic matter, useful for remediation of depleted or eroded soils. This is why untreated sludge has been used for many years as a soil fertilizer and for enhancing the organic matter of soil. A key concern is that treatment of sludge tends to concentrate heavy metals, poorly biodegradable

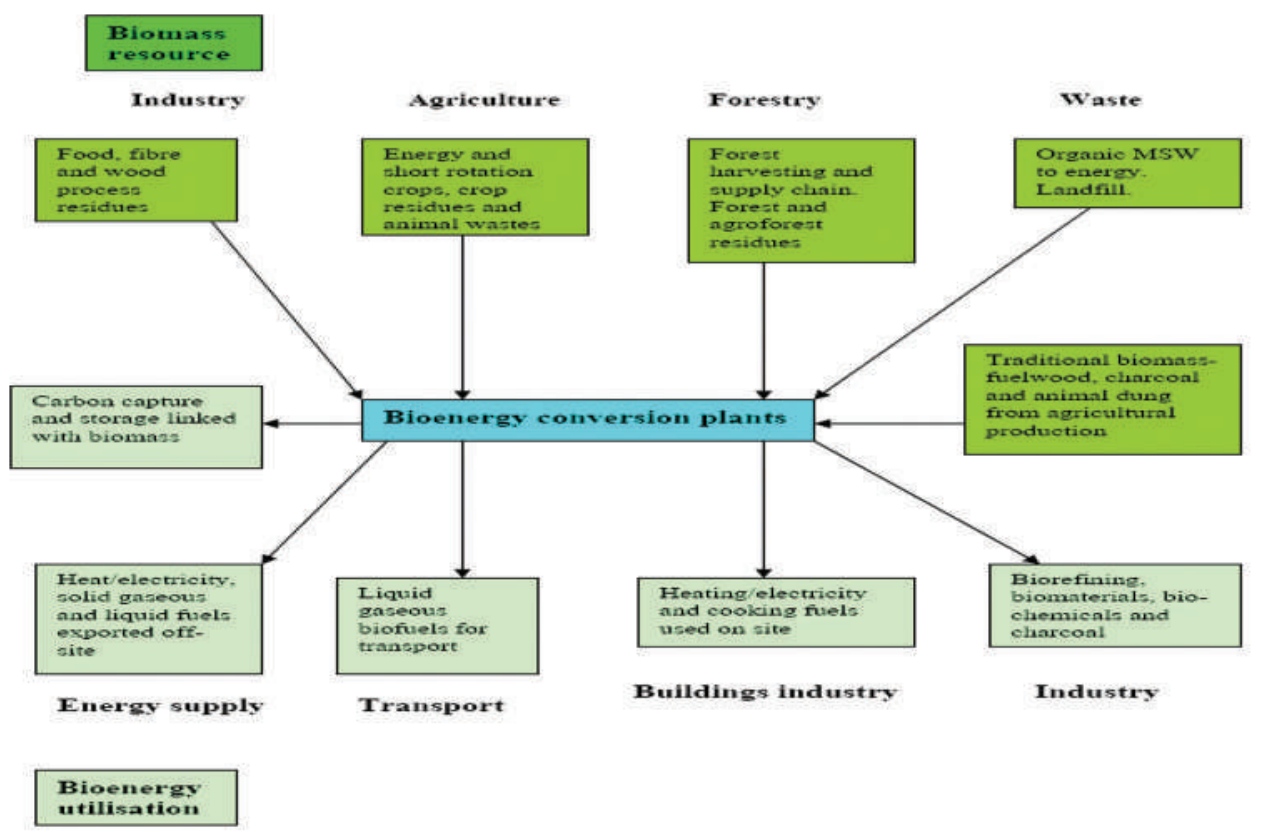

Figure 4: Biomass resources from several sources are converted into a range of products for use by transport, industry and building sectors ${ }^{[27]}$ 
Table 12: Biomass residues and current use ${ }^{[28]}$

\begin{tabular}{|c|c|}
\hline Type of residue & Current use \\
\hline Wood industry waste & Residues available \\
\hline Vegetable crop residues & Animal feed \\
\hline Food processing residue & Energy needs \\
\hline $\begin{array}{l}\text { Sorghum, millet, and } \\
\text { wheat residues }\end{array}$ & Fodder, and building materials \\
\hline Groundnut shells & $\begin{array}{l}\text { Fodder, brick making, and direct fining } \\
\text { oil mills }\end{array}$ \\
\hline Cotton stalks & $\begin{array}{l}\text { Domestic fuel considerable amounts } \\
\text { available for short period }\end{array}$ \\
\hline $\begin{array}{l}\text { Sugar, bagasse, and } \\
\text { molasses }\end{array}$ & $\begin{array}{l}\text { Fodder, energy need, and ethanol } \\
\text { production (surplus available) }\end{array}$ \\
\hline Manure & Fertilizer, brick making, and plastering \\
\hline
\end{tabular}

Table 13: Comparison of various fuels ${ }^{[28]}$

\begin{tabular}{lclc}
\hline Fuel & $\begin{array}{c}\text { Calorific } \\
\text { value (kcal) }\end{array}$ & $\begin{array}{l}\text { Burning } \\
\text { mode }\end{array}$ & $\begin{array}{c}\text { Thermal } \\
\text { efficiency (\%) }\end{array}$ \\
\hline Electricity, kWh & 880 & Hot plate & 70 \\
Coal gas, kg & 4004 & Standard burner & 60 \\
Biogas, m ${ }^{3}$ & 5373 & Standard burner & 60 \\
Kerosene, 1 & 9122 & Pressure stove & 50 \\
Charcoal, kg & 6930 & Open stove & 28 \\
Soft coke, kg & 6292 & Open stove & 28 \\
Firewood, kg & 3821 & Open stove & 17 \\
Cow dung, kg & 2092 & Open stove & 11 \\
\hline
\end{tabular}

trace organic compounds, and potentially pathogenic organisms (viruses, bacteria, and the like) present in wastewaters. These materials can pose a serious threat to the environment. When deposited in soils, heavy metals are passed through the food chain, first entering crops, and then animals that feed on the crops and eventually human beings, to whom they appear to be highly toxic. In addition, they also leach from soils, getting into groundwater and further spreading contamination in an uncontrolled manner. ${ }^{[28]}$

European and American markets aiming to transform various organic wastes (animal farm wastes, industrial, and municipal wastes) into two main by-products:

- A solution of humic substances (a liquid oxidate).

- A solid residue.

Agricultural wastes are abundantly available globally and can be converted to energy and useful chemicals by a number of microorganisms. The organic matter was biodegradable to produce biogas and the variation show a normal methanogene bacteria activity and good working biological process as shown in Figures 5-7. The success of promoting any technology depends on careful planning, management, implementation, training and monitoring. Main features of gasification project are:

- Networking and institutional development/ strengthening.

- Promotion and extension.

- Construction of demonstration projects.

- Research and development, and training and monitoring.

Biomass is a raw material that has been utilized for a wide variety of tasks since the dawn of civilization. Important as a supply of fuel in the third world, biomass was also the first raw material in the production of textiles. The gasification of the carbon char with steam can make a large difference to the surface area of the carbon. The corresponding stream gasification reactions are endothermic and demonstrate how the steam reacts with the carbon charcoal (Bacaoui, 1998).

$\mathrm{H}_{2} \mathrm{O}(\mathrm{g})+\mathrm{C}_{\mathrm{x}}(\mathrm{s}) \rightarrow \mathrm{H}_{2}(\mathrm{~g})+\mathrm{CO}(\mathrm{g})+\mathrm{C}_{\mathrm{x}-1}(\mathrm{~s})$

$\mathrm{CO}(\mathrm{g})+\mathrm{H}_{2} \mathrm{O}(\mathrm{g}) \rightarrow \mathrm{CO}_{2}(\mathrm{~g})+\mathrm{H}_{2}(\mathrm{~g})$

$\mathrm{CO}_{2}(\mathrm{~g})+\mathrm{C}_{\mathrm{x}}(\mathrm{s}) \rightarrow 2 \mathrm{CO}(\mathrm{g})+\mathrm{C}_{\mathrm{x}-1}(\mathrm{~s})$

The sources to alleviate the energy situation in the world are sufficient to supply all foreseeable needs. Conservation of energy and rationing in some form will however have to be practiced by most countries, to reduce oil imports and redress balance of payments positions. Meanwhile development and application of nuclear power and some of the traditional solar, wind and water energy alternatives must be set in hand to supplement what remains of the fossil fuels. The encouragement of greater energy use is an essential component of development. In the shortterm it requires mechanisms to enable the rapid increase in energy/capita, and in the long-term we should be working toward a way of life, which makes use of energy efficiency and without the impairment of the environment or of causing safety problems. Such a program should as far as possible be based on renewable energy resources.

\section{BIOHEAT}

Bioenergy is a growing source of power that is playing an ever-increasing role in the provision of electricity. The potential contribution of the waste industry to bioenergy is huge and has the 


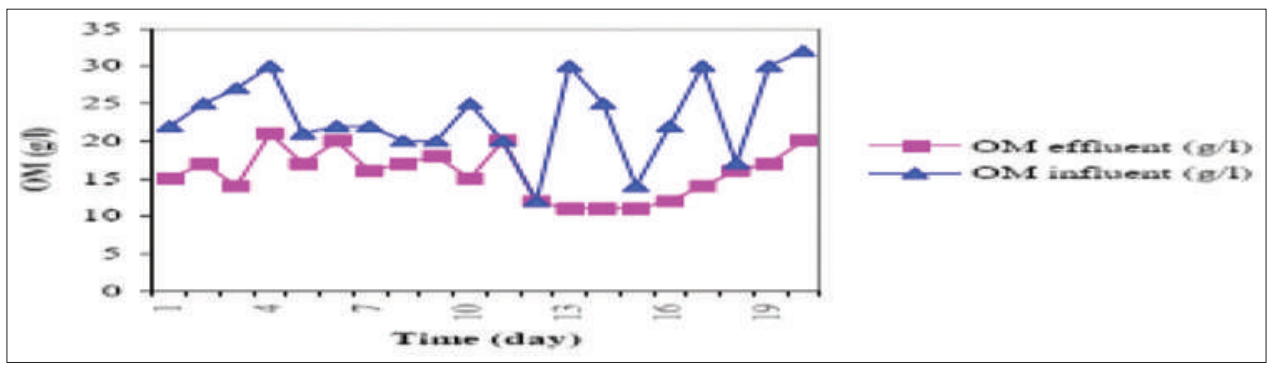

Figure 5: Organic matters before and after treatment in digester ${ }^{[29]}$

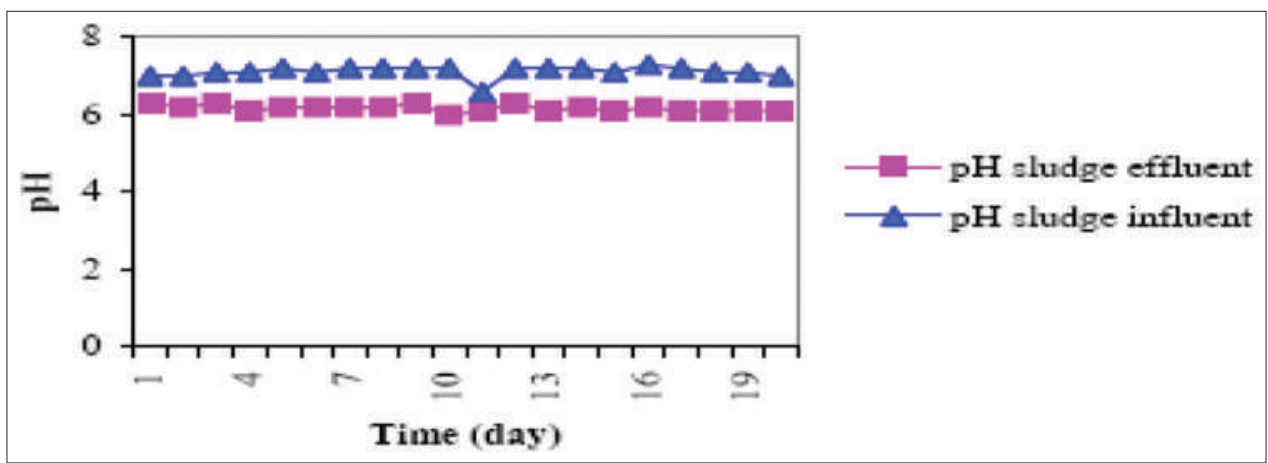

Figure 6: Potential of hydrogen $(\mathrm{pH})$ sludge before and after treatment in the digester ${ }^{[29]}$

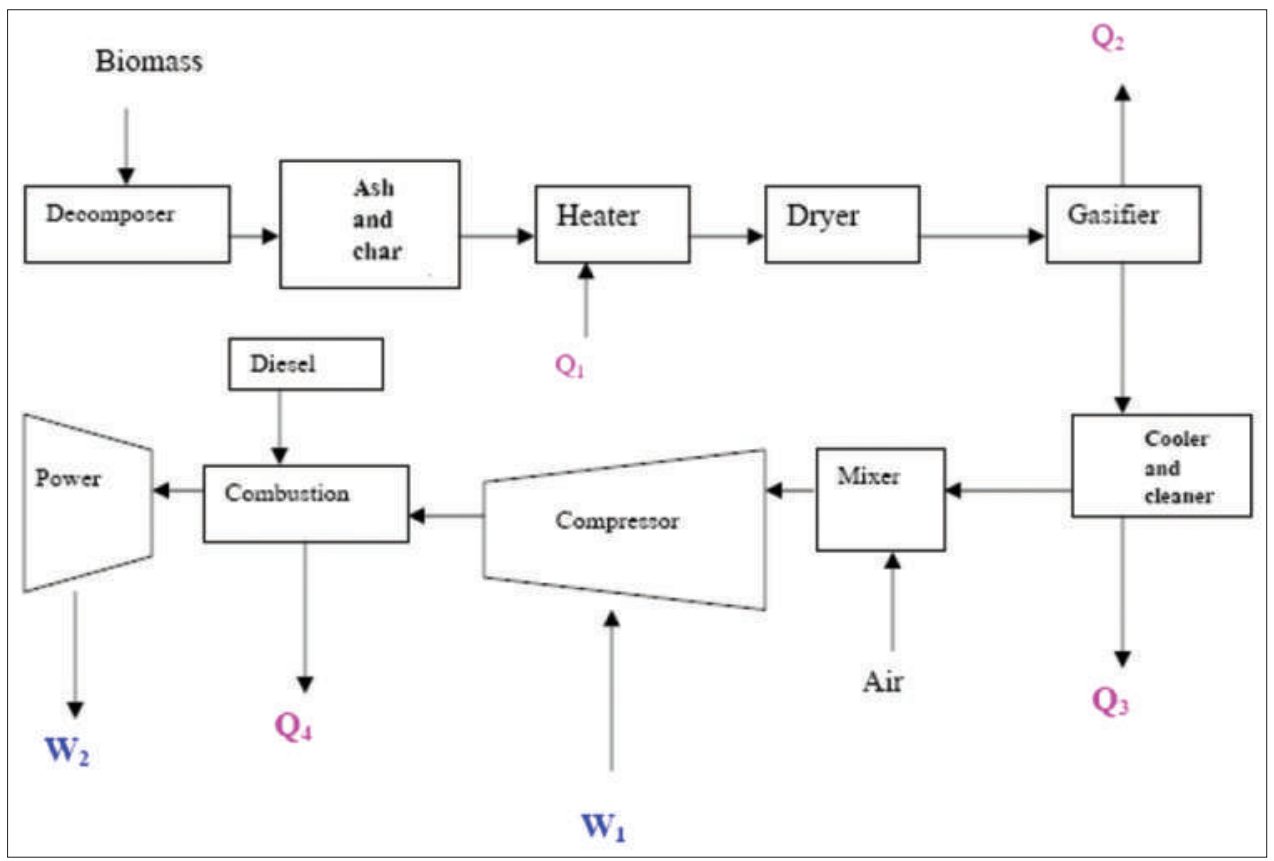

Figure 7: Advanced biomass power with diesel engine ${ }^{[30]}$

ability to account for a source of large amount of total bioenergy production. Woody biomass is usually converted into power through combustion or gasification. Biomass can be specially grown in the case of energy crops. Waste wood makes up a significant proportion of a variety of municipal, commercial, and industrial waste streams. It is common practice to dispose of this waste wood in landfill where it slowly degraded and takes up valuable void space. This wood is a good source of energy and is an alternative to energy crops. The biomass directly produced by cultivation can be transformed by different processes into gaseous, liquid, or solid fuels [Table 14]. The whole process of production of methyl or ethyl esters (biodiesel) is summarized in Figures 8,9. 
In Figure 7, advanced biomass power with diesel formed (determined by $\mathrm{Q}_{1}$ ) equals the rate at which engine at equilibrium, the rate at which vapor is it is removed. Therefore, both the heat transfer

Table 14: Biomass conversions to energy ${ }^{[29]}$

\begin{tabular}{|c|c|c|c|}
\hline Feedstock & Crops & $\begin{array}{l}\text { Conversion } \\
\text { process }\end{array}$ & $\begin{array}{l}\text { End } \\
\text { product }\end{array}$ \\
\hline $\begin{array}{l}\text { Wood-cellulosic } \\
\text { biomass } \\
\text { Vegetable oils } \\
\text { Sugar/starch }\end{array}$ & $\begin{array}{l}\text { Short rotation forest } \\
\text { (poplar, willow), plant } \\
\text { species (sorghum, } \\
\text { miscanthus, etc.), } \\
\text { fiber-crops (cynara, } \\
\text { kenaf, etc.) } \\
\text { Oleaginous crops } \\
\text { (rapeseed, soybean, } \\
\text { sunflower, etc.) } \\
\text { Cereals, root and } \\
\text { tuber crops, grape, } \\
\text { topinambor, etc. }\end{array}$ & $\begin{array}{l}\text { Direct } \\
\text { combustion } \\
\text { Gasification } \\
\text { Pyrolysis } \\
\text { Direct } \\
\text { combustion } \\
\text { Esterification } \\
\text { Fermentation }\end{array}$ & $\begin{array}{l}\text { Heat } \\
\text { Methane } \\
\text { Hydrogen } \\
\text { Oil } \\
\text { Heat } \\
\text { Biodiesel } \\
\text { Ethanol }\end{array}$ \\
\hline
\end{tabular}
rate into the liquid $\left(\mathrm{Q}_{2}\right)$ and the vapor removal rate (suction pump capacity) determines the pressure cooling capacity, that is, $\mathrm{Q}_{3} ; \mathrm{Q}_{4}$ capacity (thermal power) (Watt); and external heat input, that is, $\mathrm{W}_{1}$; $\mathrm{W}_{2}$ Heat (thermal energy) $(\mathrm{J})$.

\section{Waste policy in context}

In terms of solid waste management policy, many non-governmental organizations have changed drastically in the past 10 years from a mass production and mass consumption society to

Feedstock

production

Conversion

process

Biofuels

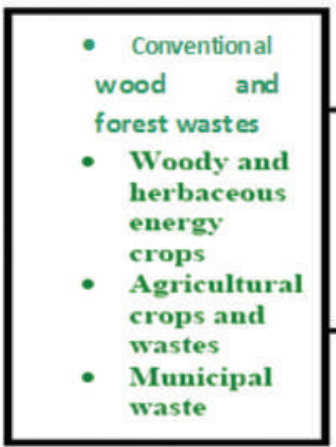

Biochemical

Alcohol

fuels

Thermochemical

Figure 8: Biofuel pathways for renewable alcohol fuels ${ }^{[30]}$

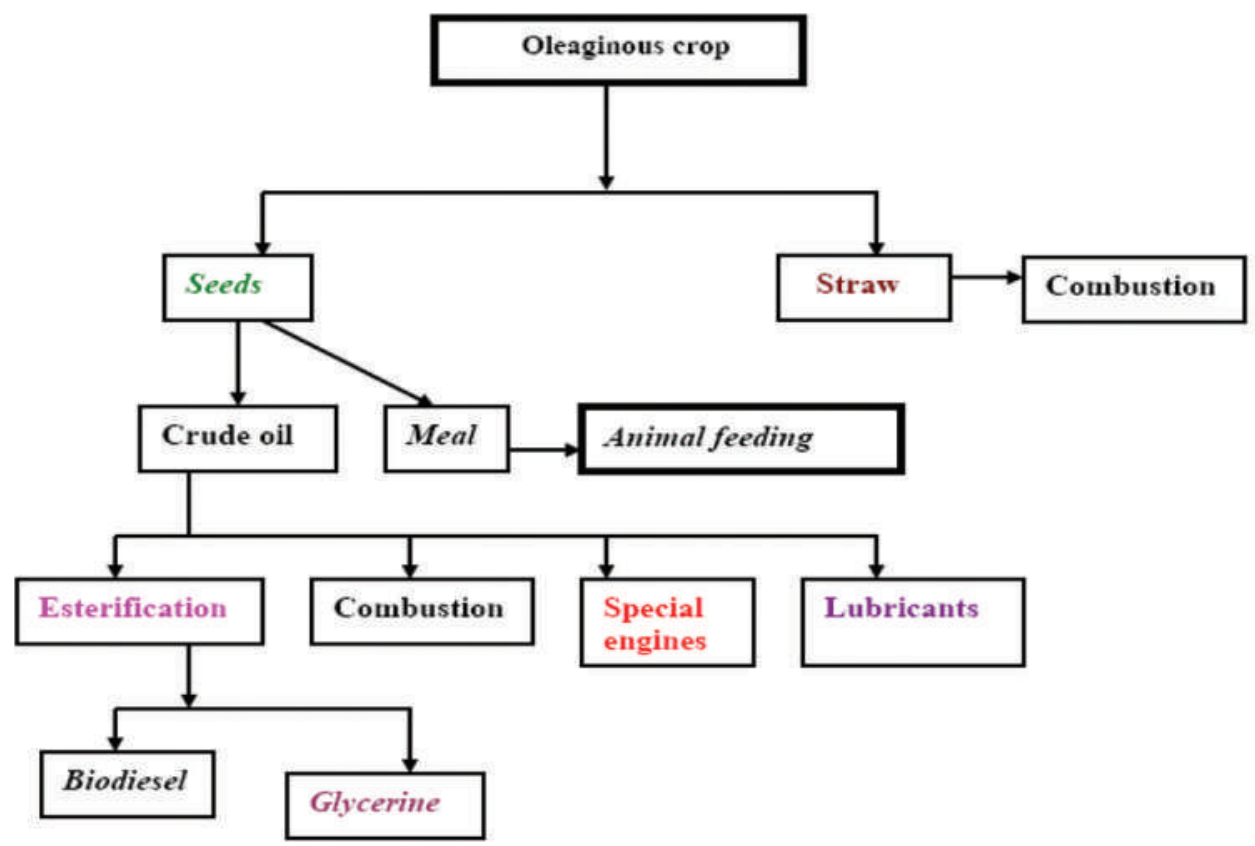

Figure 9: Flow chart of biodiesel production ${ }^{[32]}$ 
"material-cycle society." In addition to national legislation, municipalities are legally obliged to develop a plan for handling the MSW generated in administrative areas. Such plans contain:

- Estimates of future waste volume.

- Measures to reduce waste.

- Measures to encourage source separation.

- A framework for solid waste disposal and the construction and management of solid waste management facilities.

Landfilling is in the least referred tier of the hierarchy of waste management options: Waste minimization, reuse and recycling, incineration with energy recovery, and optimized final disposal. The key elements are as follows: Construction impacts, atmospheric emissions, noise, water quality, landscape, visual impacts, socio economics, ecological impacts, traffic, solid waste disposal, and cultural heritage. ${ }^{[31]}$

\section{Energy from agricultural biomass}

The main advantages are related to energy, agriculture, and environment problems, are foreseeable both at regional level and at worldwide level and can be summarized as follows:

- Reduction of dependence on import of energy and related products.

- Reduction of environmental impact of energy production (greenhouse effect, air pollution, and waste degradation).

- Substitution of food crops and reduction of food surpluses and of related economic burdens.

- Utilization of marginal lands and of set aside lands and reduction of related socio-economic and environmental problems (soil erosion, urbanization, landscape deterioration, etc.).

- Development of new know-how and production of technological innovation.

A study (Bacaoui, 1998) individuated on the basis of botanical, genetical, physiological, biochemical, agronomical, and technological knowledge reported in literature some 150 species potentially exploitable divided as reported in Table 15.

\section{ROLE OF CHEMICAL ENGINEERING}

Turning to chemical engineering and the experience of the chemical process industry represents a wakening up but does not lead to an immediate solution to the problems. The traditional techniques are not very kind to biological products, which are controlled by difficulty and unique physicochemical properties such as low mechanical, thermal, and chemical stabilities. There is the question of selectivity [Table 15].

The fermentation broths resulting from microbial growth contain a bewildering mixture of many compounds closely related to the product of interests. By the standards of the process streams in chemical industry, fermenter is highly impure and extremely dilutes aqueous systems [Table 16].

The disadvantages of the fermentation media are as the following: Mechanically fragile, temperature sensitive, rapidly deteriorating quality, and harmful if escaping into the environment,

Table 15: Plant species potentially exploitable for production of agricultural biomass for energy or industrial utilizations $^{[32]}$

\begin{tabular}{lc}
\hline Groups of plants & Number of species \\
\hline $\begin{array}{l}\text { Plants cultivated for food purposes that can } \\
\text { be reconverted to new uses }\end{array}$ & 9 \\
Plants cultivated in the past, but not in & 46 \\
culture any more & \\
Plants cultivated in other world areas & 46 \\
Wild species, both indigenous and exotic & 47 \\
Total & 148 \\
Plant product & \\
Biomass & 8 \\
Sugars and polysaccharides & 38 \\
Cellulose & 17 \\
Hydrocarbons & 3 \\
Polymeric hydrocarbons & 5 \\
Gums and resins & 12 \\
Tannins and phenolic compounds & 3 \\
Waxes & 7 \\
Vegetable oils & 38 \\
Total & 131 \\
\hline
\end{tabular}

Table 16: Typical product concentrations exiting fermenters $^{[32]}$

\begin{tabular}{lc}
\hline Product & Concentration $\mathbf{( k g / \mathbf { m } ^ { 3 } )}$ \\
\hline Ethanol & $70-120$ \\
Organic acids (e.g., citric) & $40-100$ \\
Vitamin B12 & 0.02 \\
Interferon & $50-70$ \\
Single-cell protein & $30-50$ \\
Antibiotics (e.g., Penicillin G) & $10-30$ \\
Enzyme protein (e.g., protease) & $2-5$ \\
\hline
\end{tabular}


corrosive (acids, chlorides, etc.), and troublesome (solids, theological, etc.), and expensive. Thus, pilot plants for scale-up work must be flexible. In general, they should contain suitably interconnected equipment for: Fermentation, primary separation, cell disruption fractionalizes and clarifications, purification by means of high-resolution techniques and concentration and dry. The effects of the chlorofluorocarbons (CFCs) molecule can last for over a century.

\section{FLUIDISED BED DRYING}

An important consideration for operators of wastewater treatment plants is how to handle the disposal of the residual sludge in a reliable, sustainable, legal, and economical way. The benefits of drying sludge can be seen in two main treatment options:

- Use of the dewatered sludge as a fertilizer or in fertilizer blends.

- Incineration with energy recovery.

Use as a fertilizer takes advantage of the high organic content $40-70 \%$ of the dewatered sludge and its high levels of phosphorous and other nutrients. However, there are a number of concerns about this route including:

- The chemical composition of the sludge (e.g., heavy metals, hormones, and other pharmaceutical residues).

- Pathogen risk (e.g., SALMOELLA, Escherichia coli, and Prionic proteins).

- Potential accumulation of heavy metals and other chemicals in the soil.

Sludge can be applied as a fertilizer in three forms: liquid sludge, wet cake blended into compost, and dried granules.

The advantages of energy recovery sludge include:

- The use of dewatered sludge is a "sink" for pollutants such as heavy metals, toxic organic compounds, and pharmaceutical residues. Thus, offering a potential disposal route for these substances provided the combustion plant has adequate flue gas cleaning.

- The potential, under certain circumstances, to utilize the inorganic residue from sludge incineration (incinerator ash), such as in cement or gravel.
- The high CV (similar to lignite) of dewatered sludge.

- The use of dewatered sludge as a $\mathrm{CO}_{2}$ neutral substitute for primary fuels such as oil, gas, and coal.

\section{Energy efficiency}

Energy efficiency is the most cost-effective way of cutting $\mathrm{CO}_{2}$ emissions and improvements to households and businesses. It can also have many other additional social, economic, and health benefits, such as warmer and healthier homes, lower fuel bills and company running costs and, indirectly, jobs. Britain wastes $20 \%$ of its fossil fuel and electricity use in transportation (Omer, 2006). This implies that it would be cost-effective to cut $£ 10$ billion a year off the collective fuel bill and reduce $\mathrm{CO}_{2}$ emissions by some 120 million tones $\mathrm{CO}_{2} \cdot{ }^{[33]}$ Yet, due to lack of good information and advice on energy saving, along with the capital to finance energy efficiency improvements, this huge potential for reducing energy demand is not being realized. Conventionally, energy utilities have been essentially fuel providers and the industry has pursued profits from increased volume of sales. Institutional and market arrangements have favored energy consumption rather than conservation. However, energy is at the center of the sustainable development paradigm as few activities affect the environment as much as the continually increasing use of energy. Most of the used energy depends on finite resources, such as coal, oil, gas, and uranium. In addition, more than three quarters of the world's consumption of these fuels is used, often inefficiently, by only one quarter of the world's population. Without even addressing these inequities or the precious, finite nature of these resources, the scale of environmental damage will force the reduction of the usage of these fuels long before they run out.

Throughout the energy generation process there are impacts on the environment on local, national, and international levels, from opencast mining and oil exploration to emissions of the potent $\mathrm{GHG} \mathrm{CO}_{2}$ in ever increasing concentration. Recently, the world's leading climate scientists reached an agreement that human activities, such as burning fossil fuels for energy and transport, are causing the world's temperature to 
rise. The Intergovernmental Panel on Climate Change has concluded that "the balance of evidence suggests a discernible human influence on global climate." It predicts a rate of warming greater than any one seen in the last 10,000 years, in other words, throughout human history. The exact impact of climate change is difficult to predict and will vary regionally. It could, however, include sea level rise, disrupted agriculture, and food supplies and the possibility of more freak weather events such as hurricanes and droughts. Indeed, people already are waking up to the financial and social, as well as the environmental, risks of unsustainable energy generation methods that represent the costs of the impacts of climate change, acid rain, and oil spills. The insurance industry, for example, concerned about the billion dollar costs of hurricanes and floods, has joined sides with environmentalists to lobby for GHS emissions reduction. Friends of the earth are campaigning for a more sustainable energy policy, guided by the principal of environmental protection and with the objectives of sound natural resource management and long-term energy security. The key priorities of such an energy policy must be to reduce fossil fuel use, move away from nuclear power, improve the efficiency with which energy is used and increase the amount of energy obtainable from sustainable and renewable sources. Efficient energy use has never been more crucial than it is today, particularly with the prospect of the imminent introduction of the climate change levy. Establishing an energy use action plan is the essential foundation to the elimination of energy waste. A logical starting point is to carry out an energy audit that enables the assessment of the energy use and determine what actions to take. The actions are best categorized by splitting measures into the following three general groups:

\section{High priority/low cost}

These are normally measures, which require minimal investment and can be implemented quickly. The followings are some examples of such measures:

- Good housekeeping, monitoring energy use, and targeting waste-fuel practices.

- Adjusting controls to match requirements.

- Improved greenhouse space utilization.

- Small capital item time switches, thermostats, etc.
- Carrying out minor maintenance and repairs.

- Staff education and training.

- Ensuring that energy is being purchased through the most suitable tariff or contract arrangements.

\section{Medium priority/medium cost}

Measures, which, although involve little or no design, involve greater expenditure and can take longer to implement. Examples of such measures are listed below:

- New or replacement controls.

- Greenhouse component alteration, for example, insulation, and sealing glass joints.

- Alternative equipment components, for example, energy efficient lamps in light fittings.

\section{Long-term/high cost}

These measures require detailed study and design. They can be best represented by the followings:

- Replacing or upgrading of plant and equipment.

- Fundamental redesign of systems, for example, CHP installations.

This process can often be a complex experience and therefore the most cost-effective approach is to employ an energy specialist to help.

\section{Future recommended sustainable energy policy}

Sustainability is regarded as a major consideration for both urban and rural development. People have been exploiting the natural resources with no consideration to the effects, both short-term (environmental) and long-term (resources crunch). It is also felt that knowledge and technology have not been used effectively in utilizing energy resources. Energy is the vital input for economic and social development of any country. Its sustainability is an important factor to be considered. The urban areas depend, to a large extent, on commercial energy sources. The rural areas use non-commercial sources such as firewood and agricultural wastes. With the present day trends for improving the quality of life and sustenance of mankind, environmental issues are considered highly important. In this context, the term energy loss has no significant technical meaning. Instead, the energy loss has to be considered, as destruction of energy is possible. 
Hence, energy loss minimization will help in sustainability. In the process of developing, there are two options to manage energy resources: (1) End use matching/demand side management, which focuses on the utilities. The mode of obtaining this is decided based on economic terms. It is, therefore, a quantitative approach. (2) Supply side management, which focuses on the renewable energy resource and methods of utilizing it. This is decided based on thermodynamic consideration having the resource-user temperature or energy destruction as the objective criteria. It is, therefore, a qualitative approach. The two options are explained schematically in Figure 10. The energy-based energy, developed with supply side perspective is shown in Figure 11. The following policy measures had been identified:

- Clear environmental and social objectives for energy market liberalization, including a commitment to energy efficiency and renewable.

- Economic, institutional, and regulatory frameworks, which encourage the transition to total energy services.

- Economic measures to encourage utility investment in energy efficiency (e.g., levies on fuel bills).

- Incentives for demand side management, including grants for low-income households, expert advice and training, standards for appliances and buildings and tax incentives.

- Research and development funding for renewable energy technologies not yet commercially viable.

- Continued institutional support for new renewables (such as standard cost-reflective payments and obligation on utilities to buy).

- Ecological tax reform to internalize external environmental and social costs within energy prices.

- Planning for sensitive development and public acceptability for renewable energy.

Energy resources are needed for societal development. Their sustainable development requires a supply of energy resources that are sustainably available at a reasonable cost and can cause no negative societal impacts. Energy resources such as fossil fuels are finite and lack sustainability, while renewable energy sources are sustainable over a relatively longer term. Environmental concerns are also a major factor in sustainable development, as activities, which degrade the environment, are not sustainable. Hence, as much as environmental impact is associated with energy, sustainable development requires the use of energy resources, which cause as little environmental impact as

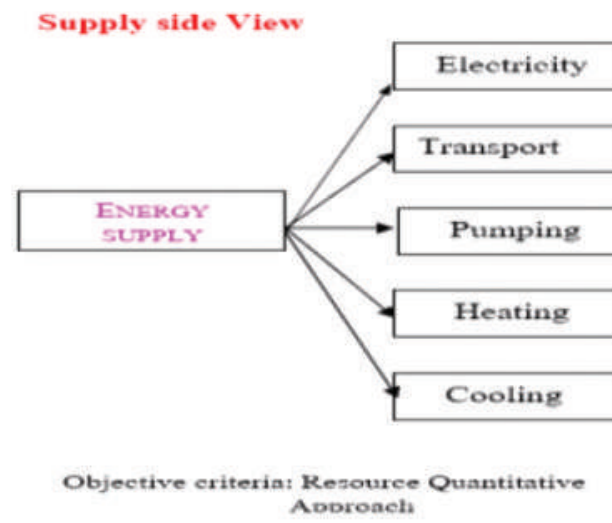

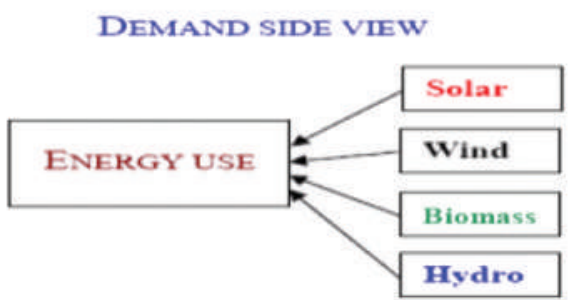

Objective criteria: Economie Quantitative Approach

Figure 10: Supply side and demand side management approach for energy ${ }^{[34]}$

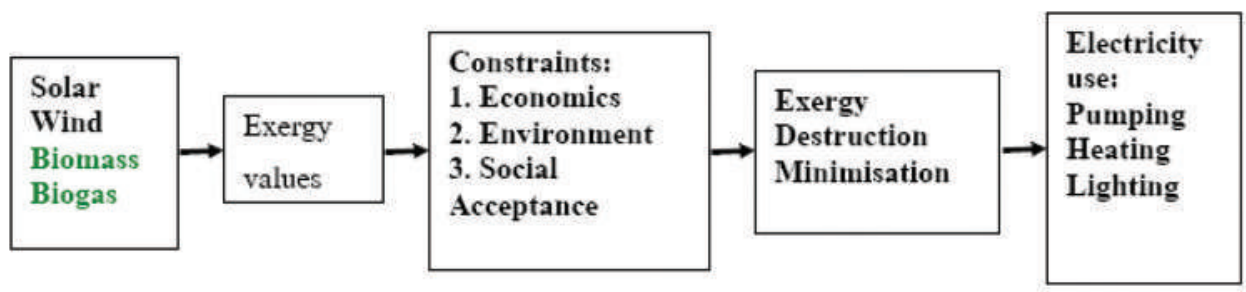

Figure 11: Energy based optimal energy model ${ }^{[34]}$ 
possible. One way to reduce the resource depletion associated with cycling is to reduce the losses that accompany the transfer of energy to consume resources by increasing the efficiency of energy transfer between resources, that is, increasing the fraction of energy removed from one resource that is transferred to another. ${ }^{[34]}$

As explained above, energy efficiency may be thought of as a more accurate measure of energy efficiency that accounts for quantity and quality aspects of energy flows. Improved energy efficiency leads to reduced energy losses. Most efficiency improvements produce direct environmental benefits in two ways. First, operating energy input requirements are reduced per unit output, and pollutants generated are correspondingly reduced. Second, consideration of the entire life cycle for energy resources and technologies suggests that improved efficiency reduces environmental impact during most stages of the life cycle. Quite often, the main concept of sustainability, which often inspires local and national authorities to incorporate environmental consideration into setting up energy programs have different meanings in different contexts though it usually embodies a long-term perspective. Future energy systems will largely be shaped by broad and powerful trends that have their roots in basic human needs. Combined with increasing world population, the need will become more apparent for successful implementation of sustainable development. ${ }^{[35]}$

Heat has a lower energy, or quality of energy, compared with work. Therefore, heat cannot be converted into work by $100 \%$ efficiency. Some examples of the difference between energy and energy are shown in Table 17.

Carnot Quality Factor $(\mathrm{CQF})=\left(1-\mathrm{T}_{\mathrm{o}} / \mathrm{T}_{\mathrm{s}}\right)$

Energy $=$ Energy $($ transferred $) \times \mathrm{CQF}$

Where $\mathrm{T}_{\mathrm{o}}$ is the environment temperature $(\mathrm{K})$ and $\mathrm{T}_{\mathrm{s}}$ is the temperature of the stream $(\mathrm{K})$.

The terms used in Table 17 have the following meanings:

Various parameters are essential to achieving sustainable development in a society. Some of them are as follows:

- Public awareness.

- Information.
Table 17: Qualities of various energy sources ${ }^{[35]}$

\begin{tabular}{lccc}
\hline Source & Energy $(\mathbf{J})$ & Energy $(\mathbf{J})$ & Carnot quality factor \\
\hline Water at $80^{\circ} \mathrm{C}$ & 100 & 16 & 0.16 \\
Steam at $120^{\circ} \mathrm{C}$ & 100 & 24 & 0.24 \\
Natural gas & 100 & 99 & 0.99 \\
Electricity/work & 100 & 100 & 1.00 \\
\hline
\end{tabular}

- Environmental education and training.

- Innovative energy strategies.

- Renewable energy sources and cleaner technologies.

- Financing.

- Monitoring and evaluation tools.

Improving access for rural and urban low-income areas in developing countries must be through energy efficiency and renewable energies. Sustainable energy is a prerequisite for development. Energybased living standards in developing countries, however, are clearly below standards in developed countries. Low levels of access to affordable and environmentally sound energy in both rural and urban low-income areas are therefore a predominant issue in developing countries. In recent years many programs for development aid or technical assistance have been focusing on improving access to sustainable energy, many of them with impressive results. ${ }^{[36]}$

Apart from success stories, however, experience also shows that positive appraisals of many projects evaporate after completion and vanishing of the implementation expert team. Altogether, the diffusion of sustainable technologies such as energy efficiency and renewable energies for cooking, heating, lighting, electrical appliances, and building insulation in developing countries has been slow. Energy efficiency and renewable energy programs could be more sustainable and pilot studies more effective and pulse releasing if the entire policy and implementation process were considered and redesigned from the outset. New financing and implementation processes are needed which allow reallocating financial resources and thus enabling countries themselves to achieve a sustainable energy infrastructure. The links between the energy policy framework, financing, and implementation of renewable energy and energy efficiency projects have to be strengthened and capacity building efforts are required. 


\section{RESULTS AND DISCUSSION}

The presented study is general review on the potential and use of bioenergy. It highlights some assets and disadvantages of this type of energy source focusing on sustainability aspects. ${ }^{[37,38]}$ Furthermore, the following action areas for producers were recommended:

- Management and measurement tools-Adopting environmental management systems appropriate for the business.

- Performance assessment tools - Making use of benchmarking to identify scope for impact reduction and greater eco-efficiency in all aspects of the business.

- Best practice tools - Making use of free help and advice from government best practice programs (energy efficiency, environmental technology, and resource savings).

- Innovation and ecodesign - Rethinking the delivery of "value added" by the business, so that impact reduction and resource efficiency are firmly built in at the design stage.

- Cleaner, leaner production processes - Pursuing improvements and savings in waste minimization, energy and water consumption, transport and distribution, as well as reduced emissions.

- Supply chain management - Specifying more demanding standards of sustainability from "upstream" suppliers, while supporting smaller firms to meet those higher standards.
- $\quad$ Product stewardship - Taking the broadest view of "producer responsibility" and working to reduce all the "downstream" effects of products after they have been sold on to customers.

- Openness and transparency - Publicly reporting on environmental performance against meaningful targets; actively using clear labels and declarations so that customers are fully informed; building stakeholder confidence by communicating sustainability aims to the workforce, the shareholders, and the local community [Figure 12].

Alternatively energy sources can potentially help fulfill the acute energy demand and sustain economic growth in many regions of the world. Bioenergy is beginning to gain importance in the global fight to prevent climate change. The scope for exploiting organic waste as a source of energy is not limited to direct incineration or burning refuse-derived fuels. Biogas, biofuels, and woody biomass are other forms of energy sources that can be derived from organic waste materials. These biomass energy sources have significant potential in the fight against climate change. Recently, there are many studies on modern biomass energy technology systems published. ${ }^{[40]}$

This is the step in a long journey to encourage a progressive economy, which continues to provide people with high living standards, but at the same time, helps reduce pollution, waste mountains, other environmental degradation, and environmental

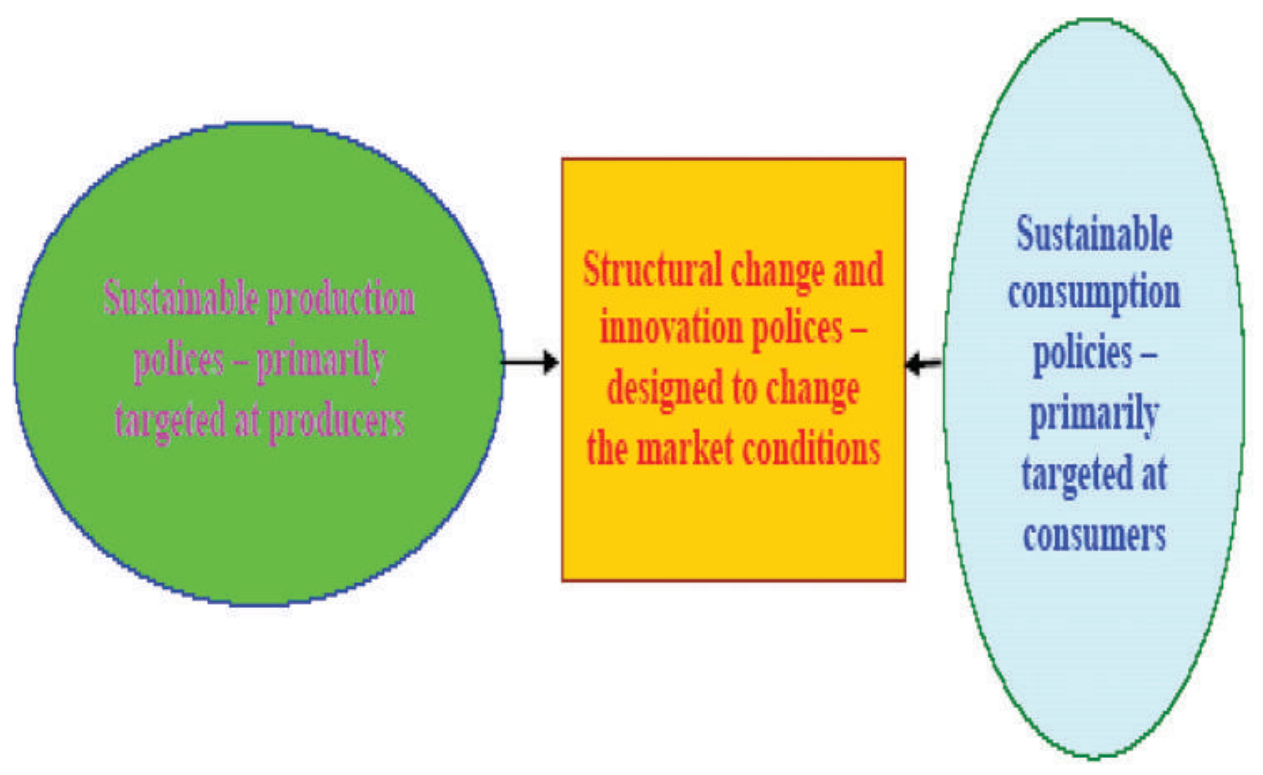

Figure 12: Link between resources and productivity ${ }^{[39]}$ 
rationale for future policy-making and intervention to improve market mechanisms. This vision will be accomplished by:

- "Decoupling" economic growth and environmental degradation. The basket of indicators illustrated shows the progress being made [Table 18]. Decoupling air and water pollution from growth, making good headway with $\mathrm{CO}_{2}$ emissions from energy, and transport. The environmental impact of our own individual behavior is more closely linked to consumption expenditure than the economy as a whole.

- Focusing policy on the most important environmental impacts associated with the use of particular resources, rather than on the total level of all resource use.

- Increasing the productivity of material and energy use that are economically efficient by encouraging patterns of supply and demand, which are more efficient in the use of natural resources. The aim is to promote innovation and competitiveness. Investment in areas such as energy efficiency, water efficiency, and waste minimization.

- Encouraging and enabling active and informed individual and corporate consumers.

Vegetation and in particular forests can be managed to sequester carbon. Management options have been identified to conserve and sequester up to $90 \mathrm{Pg} \mathrm{C}$ in the forest sector in the next century, through global afforestation. ${ }^{[41]}$ For efficient use of bioenergy

Table 18: The basket of indicators for sustainable consumption and production ${ }^{[39]}$

\footnotetext{
Economy-wide decoupling indicators

1. Greenhouse gas emissions

2. Air pollution

3. Water pollution (river water quality)

4. Commercial and industrial waste arising's and household waste not cycled

Resource use indicators

1. Material use

2. Water abstraction

3. Homes built on land not previously developed, and number of households

Decoupling indicators for specific sectors

1. Emissions from electricity generation

2. Motor vehicle kilometers and related emissions

3. Agricultural output, fertilizer use, methane emissions, and farmland bird populations

4. Manufacturing output, energy consumption, and related emissions

5. Household consumption, expenditure energy, water consumption, and waste generated
}

resources, it is essential to take account of the intrinsic energy potential. Despite the availability of basic statistics, many differences have been observed between the previous assessments of bioenergy potential. ${ }^{[41]}$

On some climate change issues (e.g., global warming), there is no disagreement among the scientists. The greenhouse effect is unquestionably real; it is essential for life on earth. Water vapor is the most important $\mathrm{GHG}$; followed by $\mathrm{CO}_{2}$. Without a natural greenhouse effect, scientists estimate that the earth's average temperature would be $-18^{\circ} \mathrm{C}$ instead of its present $14^{\circ} \mathrm{C} .{ }^{[41]}$ There is also no scientific debate over the fact that human activity has increased the concentration of the GHGs in the atmosphere (especially $\mathrm{CO}_{2}$ from combustion of coal, oil, and gas). The greenhouse effect is also being amplified by increased concentrations of other gases, such as methane, nitrous oxide, and CFCs as a result of human emissions. Most scientists predict that rising global temperatures will raise the sea level and increase the frequency of intense rain or snowstorms (Andrea, and Fernando, 2012).

Globally, buildings are responsible for approximately $40 \%$ of the total world annual energy consumption. Most of this energy is for the provision of lighting, heating, cooling, and air conditioning. Increasing awareness of the environmental impact of $\mathrm{CO}_{2}, \mathrm{NO}_{x}$, and $\mathrm{CFCs}$ emissions triggered a renewed interest in environmentally friendly cooling, and heating technologies. Under the 1997 Montreal Protocol, governments agreed to phase out chemicals used as refrigerants that have the potential to destroy stratospheric ozone. It was, therefore, considered desirable to reduce energy consumption and decreases the rate of depletion of world energy reserves and pollution of the environment. One way of reducing building energy consumption is to design buildings, which are more economical in their use of energy for heating, lighting, cooling, ventilation, and hot water supply. Passive measures, particularly natural or hybrid ventilation rather than air-conditioning, can dramatically reduce primary energy consumption. However, exploitation of renewable energy in buildings and agricultural greenhouses can, also, significantly contribute towards reducing dependency on fossil fuels. Therefore, promoting innovative renewable applications and reinforcing the renewable energy 
market will contribute to preservation of the ecosystem by reducing emissions at local and global levels. ${ }^{[42]}$

The adoption of green or sustainable approaches to the way in which society is run is seen as an important strategy in finding a solution to the energy problem. The key factors to reducing and controlling $\mathrm{CO}_{2}$, which is the major contributor to global warming, are the use of alternative approaches to energy generation and the exploration of how these alternatives are used today and may be used in the future as green energy sources. Even with modest assumptions about the availability of land, comprehensive fuel-wood farming programs offer significant energy, economic, and environmental benefits. These benefits would be dispersed in rural areas where they are greatly needed and can serve as linkages for further rural economic development. The nations as a whole would benefit from savings in foreign exchange, improved energy security, and socio-economic improvements. With a nine-fold increase in forest - plantation cover, a nation's resource base would be greatly improved. The international community would benefit from pollution reduction, climate mitigation, and the increased trading opportunities that arise from new income sources.

\section{CONCLUSION}

Even with modest assumptions about the availability of land, comprehensive fuel-wood farming programs offer significant energy, economic, and environmental benefits. These benefits would be dispersed in rural areas where they are greatly needed and can serve as linkages for further rural economic development. The nations, as a whole would benefit from savings in foreign exchange, improved energy security, and socio-economic improvements. With a nine-fold increase in forest - plantation cover, the nation's resource base would be greatly improved. The international community would benefit from pollution reduction, climate mitigation, and the increased trading opportunities that arise from new income sources. Furthermore, investigating the potential is needed to make use of more and more of its waste. Household waste, vegetable market waste, and waste from the cotton stalks, leather, and pulp; and paper industries can be used to produce useful energy either by direct incineration, gasification, digestion (biogas production), fermentation, or cogeneration. Therefore, effort has to be made to reduce fossil energy use and to promote green energies, particularly in the building sector. Energy use reductions can be achieved by minimizing the energy demand, by rational energy use, by recovering heat, and the use of more green energies. This study was a step toward achieving that goal.

\section{ACKNOWLEDGMENTS}

The financial support for this research work from the Associate Researcher at Energy Research Institute (ERI), Nottingham, UK is gratefully acknowledged. I am grateful to my wife Kawthar Abdelhai Ali for standing beside me.

\section{REFERENCES}

1. Abdeen MO. Utilisation of biomass for renewable bioenergy development. Int J Compr Res Biol Sci 2015;2:1-28.

2. Abdeen MO. Renewable building energy systems and passive human comfort solutions. Renew Sustain Energy Rev 2008a;12:1562-87.

3. Abdeen MO. People, power and pollution. Renew Sustain Energy Rev 2008b;12:1864-89.

4. Abdeen MO. Energy, environment and sustainable development. Renew Sustain Energy Rev 2008c;12:2265300 .

5. Abdeen MO. Focus on low carbon technologies: The positive solution. Renew Sustain Energy Rev 2008d;12:2331-57.

6. Abdeen MO. Chapter 10: Development of integrated bioenergy for improvement of quality of life of poor people in developing countries. In: Magnusson FL, Bengtsson OW, editors. Energy in Europe: Economics, Policy and Strategy. New York: NOVA Science Publishers; 2008e. p. 341-73.

7. Abdeen MO. Environmental and socio-economic aspect of possible development in renewable energy use. In: Proceedings of the $4^{\text {th }}$ International Symposium on Environment, Athens, Greece, 21-24 May 2009; 2009a.

8. Abdeen MO. Energy use, environment and sustainable development. In: Proceedings of the $3^{\text {rd }}$ International Conference on Sustainable Energy and Environmental Protection (SEEP 2009), Paper No. 1011. Dublin: Republic of Ireland; 2009b.

9. Abdeen MO. Energy use and environmental: Impacts: A general review. J Renew Sustain Energy 2009c;1:1-29.

10. Abdeen MO. Chapter 3: Energy Use, Environment and Sustainable Development. In: Mancuso RT, editor. 
Environmental Cost Management. New York: NOVA Science Publishers; 2009d. p. 129-66.

11. Aladjadjiyan A, Kakanakov R. The role of RES in future power supply of Bulgaria. In: Gubina A, editor. $7^{\text {th }}$ Balkan Power Conference, Sibenik, Croatia, 10-12 September 2008, Proceedings. Slovenia: University of Ljubljana; 2008.

12. Aladjadjiyan A, Kakanakov R, Zahariev A. Biomass energy resources in estimation and sustainable incorporation of biomass and other RES in municipal and national strategies for energy development. Scopie 2010;4:88-95.

13. Aleksandar Z, Dimo P, Anna A. Biogas from animal manure-perspectives and barriers in Bulgaria. Annu Res Rev Biol 2014;4:709-19.

14. Andrea S, Fernando R. Identifying, developing, and moving sustainable communities through renewable energy. World J Sci Technol Sustain Dev 2012;9:273-81.

15. Aroyeun SO. Reduction of aflatoxin B1 and Ochratoxin A in cocoa beans infected with Aspergillus via ergosterol value. World Rev Sci Technol Sustain Dev 2009;6:75-90.

16. Bacaoui A, Yaacoubi A, Dahbi C, Bennouna J, Mazet A. Activated carbon production from Moroccan olive wastes-influence of some factors. Environ Technol 1998;19:1203-12.

17. Barton AL. Focus on Sustainable Development Research Advances. New York: NOVA Science Publishers, Inc.; 2007. p. 189-205.

18. Bessou S. Biofuels, greenhouse gases and climate change. Agron Sustain Dev 2009;31:1-79.

19. Bhutto A, Bazmi A, Zahwdi G. Greener energy: Issues and challenges for Pakistan-biomass energy prospective. Renew Sustain Energy Rev 2011;15:3207-19.

20. Brain G, Mark S. Garbage in, energy out: Landfill gas opportunities for CHP projects. Cogeneration and on-site power. J Cogener Power 2007;8:37-45.

21. Cheng R. Advanced Biofuel Technologies: Status and Barriers, World Bank Report No. WPS5411; 2010.

22. Cihan G, Dursun B, Bora A, Erkan S. Importance of biomass energy as alternative to other sources in Turkey. Energy Policy 2009;37:424-31.

23. D'Apote SL. IEA biomass energy analysis and projections. In: Proceedings of Biomass Energy Conference: Data, Analysis and Trends. Paris: OECD; 1998.

24. Duku B. Comprehensive review of biomass resources and biofuels potential in Ghana. Renew Sustain Energy Rev 2009;15:404-15.

25. Erlich P. Forward facing up to climate change. In: Wyman RC, editor. Global Climate Change and Life on
Earth. London: Chapman and Hall; 1991.

26. Hall O, Scrase J. Will biomass be the environmentally friendly fuel of the future? Biomass Bioenergy 1998;15:357-67.

27. Jeremy L. The energy crisis, global warming and the role of renewables. Renew Energy World 2005;8:23-34.

28. Kothari DP, Singal KC, Rakesh R. Renewable Energy Sources and Emerging Technologies. $2^{\text {nd }}$ ed. New Delhi: Private Ltd.; 2011.

29. Lattimore B. Environmental factors in woodfuel production-opportunities, risks, and criteria and indicators for sustainable practices. Biomass Bioenergy 2009;33:1321-42.

30. Levine M, Hirose M. Energy Efficiency Improvement Utilising High Technology: An Assessment of Energy Use in Industry and Buildings. Report and Case Studies. London, UK: World Energy Council; 2005.

31. Omer AM. Review: Organic waste treatment for power production and energy supply. Cells Anim Biol 2006;1:34-47.

32. Omer AM. Renewable energy resources for electricity generation in Sudan. Renew Sustain Energy Rev 2007;11:1481-97.

33. Omer AM. Green energies and environment. Renew Sustain Energy Rev 2008;12:1789-821.

34. Omer AM, Yemen F. Biogas energy technology in Sudan. Renew Energy 2003;28:499-507.

35. Pernille M. Feature: Danish lessons on district heating. In: Energy Resource Sustainable Management and Environmental March/April 2004, 16-17; 2004.

36. Robinson G. Changes in Construction Waste Management. Waste Management World; 2007. p. 43-9.

37. Rossi S, Arnone S, Lai A, Lapenta E, Sonnino A. ENEA's activities for developing new crops for energy and industry. In: Grassi G, Gosse G, dos Santos G, editors. Biomass for Energy and Industry. Vol. 1. London, New York: Elsevier Applied Science; 1990. p. 107-13.

38. Rural Industries Research and Development Corporation. Sustainability Production of Bioenergy: A Review of Global Bioenergy Sustainability framewOrks and Assessment Systems; 2009.

39. Sims RH. Not too late: IPCC identifies renewable energy as a key measure to limit climate change. Renew Energy World 2007;10:31-9.

40. Singh A. Biomass conversion to energy in India: A critique. Renew Sustain Energy Rev 2008;14:1367-78.

41. Wu J, Boggess W. The optimal allocation of conservation funds. J Environ Econ Manag 1999;38:12-20.

42. Zahariev A, Kostadinova SV, Aladjadjiyan A. Composting municipal waste for soil re-cultivation in Bulgaria. Int $\mathrm{J}$ Plant Soil Sci 2014;3:178-85. 